\section{Effect of the Parafunctional Occlusal Loading and Crown Height on Stress Distribution}

Leonardo Bueno Torcato, Eduardo Piza Pellizzer, Fellippo Ramos Verri, Rosse Mary Falcón-Antenucci, Victor Eduardo de Souza Batista, Leonardo Ferreira de Toledo Piza Lopes.
Department of Dental Materials and Prosthodontics, Araçatuba Dental School, UNESP - Univ Estadual Paulista, Araçatuba, SP, Brazil

Correspondence: Rosse Mary FalcónAntenucci, Rua José Bonifácio 1193, Vila Mendonça, 16015-050 Araçatuba, SP, Brasil. Tel.: +55-18-3636-3297. e-mail: rosse_falcon@yahoo.com.br

\begin{abstract}
The aim of this study was to assess, by the three-dimensional finite element method, the influence of crown-to-implant ratio and parafunctional occlusal loading on stress distribution in single external hexagon implant-supported prosthesis. Computer-aided design software was used to confection three models. Each model was composed of a block bone and an external hexagon implant $(5 \times 10.0 \mathrm{~mm})$ with screw-retained implant prostheses, varying the height crown: $10,12.5$ and $15 \mathrm{~mm}$. Finite element analysis software was used to generate the finite element mesh and to establish the loading and boundary conditions. Normal ( $200 \mathrm{~N}$ axial and $100 \mathrm{~N}$ oblique load) and parafunctional forces $(1,000 \mathrm{~N}$ axial and $500 \mathrm{~N}$ oblique load) were applied. The results were visualized by von Mises and maximum principal stress. In comparison with the normal occlusal force, the parafunctional occlusal force induced an increase in stress concentration and magnitude on implant (platform and first threads) and screw (neck). The cortical bone showed the highest tensile stress under parafunctional force (oblique load). The stress concentration increased as the crown height increased. It was concluded that: increasing the $\mathrm{C} / \mathrm{I}$ increased stress concentration in both implant components and cortical bone; parafunctional loading increased between 4-5 times the value of stresses in bone tissue compared with functional loading; the type of loading variation factor is more influential than the crown-to-implant factor.
\end{abstract}

Key Words: finite element analysis, implant-supported prostheses, parafunctional load.

\section{Introduction}

The use of osseointegrated dental implants for replacing teeth is a viable option, especially in the restoration of single edentulous spaces. Despite the high rates of success and survival, the implant supported prostheses are still subjected to biological and biomechanical complications (1).

Occlusal overload, unfavorable crown-to-implant ratio $(\mathrm{C} / \mathrm{I})$, cantilevers, the size of occlusal table and non-axial loads are some of the prosthetic factors that often involve dental implant failures. So, from a biomechanical point of view, an adequate transfer of occlusal loads to bone tissue through the components is very important for the prosthesis success (2).

According to Laney (3), C/I refers to the relation between restoration height and length of the implant incorporated into bone tissue. Differently from natural teeth, two types of $\mathrm{C} / \mathrm{I}$ can be defined: anatomic $\mathrm{C} / \mathrm{I}$, where the lever arm fulcrum is located in the region of implant/abutment interface, and clinical C/I, located in the area of bone/ implant contact (4).

Clinically, bone resorption presents two serious challenges for Implantology: the absence of enough bone tissue for implant placement and a subsequent alteration of occlusal vertical dimension, which is typically associated with cosmetic problems. It leads to the use of shorter implants due to absorption or use of higher crowns, which alters the crown/root ratio associated with natural dentition (5). Although C/ls between 0.5 and 1 have been proposed to prevent stresses in peri-implant region and the consequent bone loss, as well as any implant failure, no clinical protocol has been established yet (6).

Thus, the use of short implants in association with atrophic jaw has been considered a risk factor because of the increased maxillary-mandibular relation, where installation of higher crowns is required, which favors the emergence of an unfavorable crown/implant proportion (7). This unfavorable proportion can result in excessive nonaxial loads that increase the likelihood of force moments and stresses on prosthetic components and bone tissue from peri-implant cervical region (6).

Complications such as loosening of the crown retaining screw, fracture of prosthetic components, cervical bone loss, and microdeformations (between 2,000 and 3,000 microstrain) or microfractures (above 4,000 microstrain) in bone/implant interface reported in animal and human model studies, are some consequences of implant overloading (8). However, it should be noted that the maximum occlusal force applied and tolerated varies greatly 
according to implant position in the arch, functional and/ or parafunctional (bruxism) habits, as well as the nature of antagonist teeth (9).

Some authors have suggested that the influence of occlusal overload originated from parafunctional habits, such as bruxism over dental implants and their components provides a greater risk of biological and biomechanical complications in comparison with physiological chewing activities (10). However, according to Lobbezoo (11), there are still no scientific evidences about this subject. Within this context of clinical studies, the author shows that the cause/effect relationship between bruxism and implant loss is not enough, since the criteria used to validate the causeeffect relationship are not present in the articles evaluated in this review. Therefore, due to the lack of studies that clarify this relation, the three-dimensional finite element method can be used as an alternative for the evaluation and prediction of areas with greater potential for failures in the bone-implant-crown set.

The purpose of this study was to assess, by a threedimensional finite element method, the influence of $\mathrm{C} / \mathrm{I}$ and parafunctional occlusal loading on stress distribution in single external hexagon implant-supported prosthesis. The hypotheses of the study were: i) Parafunctional loading will induce greater stresses on bone-implant-crown set, ii) The maximum crown height will produce higher stresses at crown/implant set or bone tissue.

\section{Materials and Methods}

Three models were created. Each model was composed of a mandibular molar bone block (cortical and trabecular), one external hexagon implant (5x10 mm) (Master Screw; Conexão Sistema de Prótese Ltda., Arujá, SP, Brazil) and a screw-retained single crown.

\section{Model Design}

The external hexagon implant and UCLA abutment geometries were used as reference to create the 3D design. These images were simplified by SolidWorks 2010 (SolidWorks Corp, Waltham, MA, USA) and Rhinoceros 4.0 softwares (NURBS modeling for Windows; Robert McNeel \&t Associates, Seattle, WA, USA).

A screw-retained single crown was simulated using a $20^{\circ}$ cusp inclination. The crown framework was fabricated from nickel-chromium alloy and feldspathic porcelain was used as veneering material like porcelain-fused-to-metal dental crown. The crown design was obtained from an artificial mandibular molar tooth (Odontofix Indústria e Comércio de Material Odontológico Ltda., Ribeirão Preto, SP, Brazil), and digitized using a 3D scanner (MDX-20; Roland DG, São Paulo SP, Brazil). The images were exported to Rhinoceros 4.0 CAD software for modeling and occlusal surface details were added using SolidWorks CAD software. The simulated crown heights were: $10,12.5$ and $15 \mathrm{~mm}$ (12).

The bone block was obtained by a CT scan arrangement using InVesalius software (CTI Renato Archer, Campinas, SP, Brazil) and it was simplified by Rhinoceros 4.0 software.

\section{Material Properties, Loading and Boundary Conditions}

After the modeling phase, all geometries were exported to finite element software (FEMAP 10.2; Siemens PLM Software Inc., Plano, TX, USA) for pre and post-processing. The first step was to obtain the meshes using tetrahedral parabolic solid elements for all the structures involved. The models had 268,880 elements and 407,172 nodes in model A, 334,590 elements and 503,816 nodes in model $B$ and 482,920 elements and 318,929 nodes in model C.

The mechanical properties, such as elastic modulus and Poisson's coefficient of each material, were incorporated according to the values obtained in literature (13-16), as shown in Table 1. All materials were considered isotropic, linearly elastic and homogeneous.

The crown/abutment and abutment/implant contacts were assumed to be symmetric and all other contacts were assumed to be symmetrically welded. The constraint definitions were established as fixed in $x, y$, and $z$ axes at the mesial and distal boundary surfaces of cortical and trabecular bone. All other model surfaces were unrestricted. The load was applied in axial and oblique directions. A normal occlusal force (200 N axial and $100 \mathrm{~N}$ oblique) and a parafunctional occlusal force $(1,000 \mathrm{~N}$ axial and $500 \mathrm{~N}$ oblique) were applied on the crown's occlusal surface. The axial load was distributed into four points on the cusps' internal slope, while the oblique load was divided into two loading points.

The analysis was generated in FEMAP 10.2 and exported to processing on NeiNastran 9.2b (Noran Engineering, Inc., Westminster, CA, USA) finite element software. Afterwards, the results were imported to FEMAP 10.2 for von Mises and maximum principal stress map plotting.

Table 1. Materials properties

\begin{tabular}{lccc}
\hline Material & $\begin{array}{c}\text { Young's } \\
\text { modulus (GPa) }\end{array}$ & $\begin{array}{c}\text { Poisson's } \\
\text { ratio }\end{array}$ & Reference \\
\hline $\begin{array}{l}\text { Trabecular bone } \\
\text { Cortical bone }\end{array}$ & 1.37 & 0.30 & Sevimay et al. (20) \\
$\begin{array}{l}\text { Titanium } \\
\text { Ni-Cr alloy }\end{array}$ & 110.7 & 0.30 & Sertgoz et al. (21) \\
$\begin{array}{l}\text { Feldspathic } \\
\text { porcelain }\end{array}$ & 206.0 & 0.35 & $\begin{array}{c}\text { Sertgoz et al. (21) } \\
\text { Anusavice and } \\
\text { Hojjatie (22) }\end{array}$ \\
\hline
\end{tabular}




\section{Criteria Stress Analysis}

The von Mises stress analysis was used for implantprosthetic components and implant (ductile materials). The maximum principal stress value was used as the evaluation criterion for cortical and trabecular bone (brittle materials). This criterion offers the possibility of making a distinction between tensile and compressive stresses. Positive values represent tensile stress; negative values represent compressive stresses. The measurement unit in this study was MegaPascal (MPa).

\section{Results}

Implant

Under functional axial loading, stresses were observed between the platform and first implant thread and on regions around the screw (2.5 to $3 \mathrm{MPa}$ ), for the three models. However, models $B$ and $C$ exhibited higher stress areas with the same magnitude (1-3 MPa). Under parafunctional loading, model A (Fig. 1A) showed stresses in the region of threads at screw level, while models $B$ and $C$ (Figs. 1B and $1 C$ ) showed a similar pattern of stress distribution. The highest stresses were between 6.667 and $11.33 \mathrm{MPa}$.

Under functional oblique loading, all models presented stress areas located in the hexagon region and implant platform on the same side of load application and in the first threads of the contralateral side, and model $\mathrm{C}$ showed the greatest stress areas, between 50-63.33 MPa. Under parafunctional loading, a high intensity stress concentration was found in the same areas, but in a greater area (Figs 1D, 1E and 1F). Model C (Fig. 1E) presented the
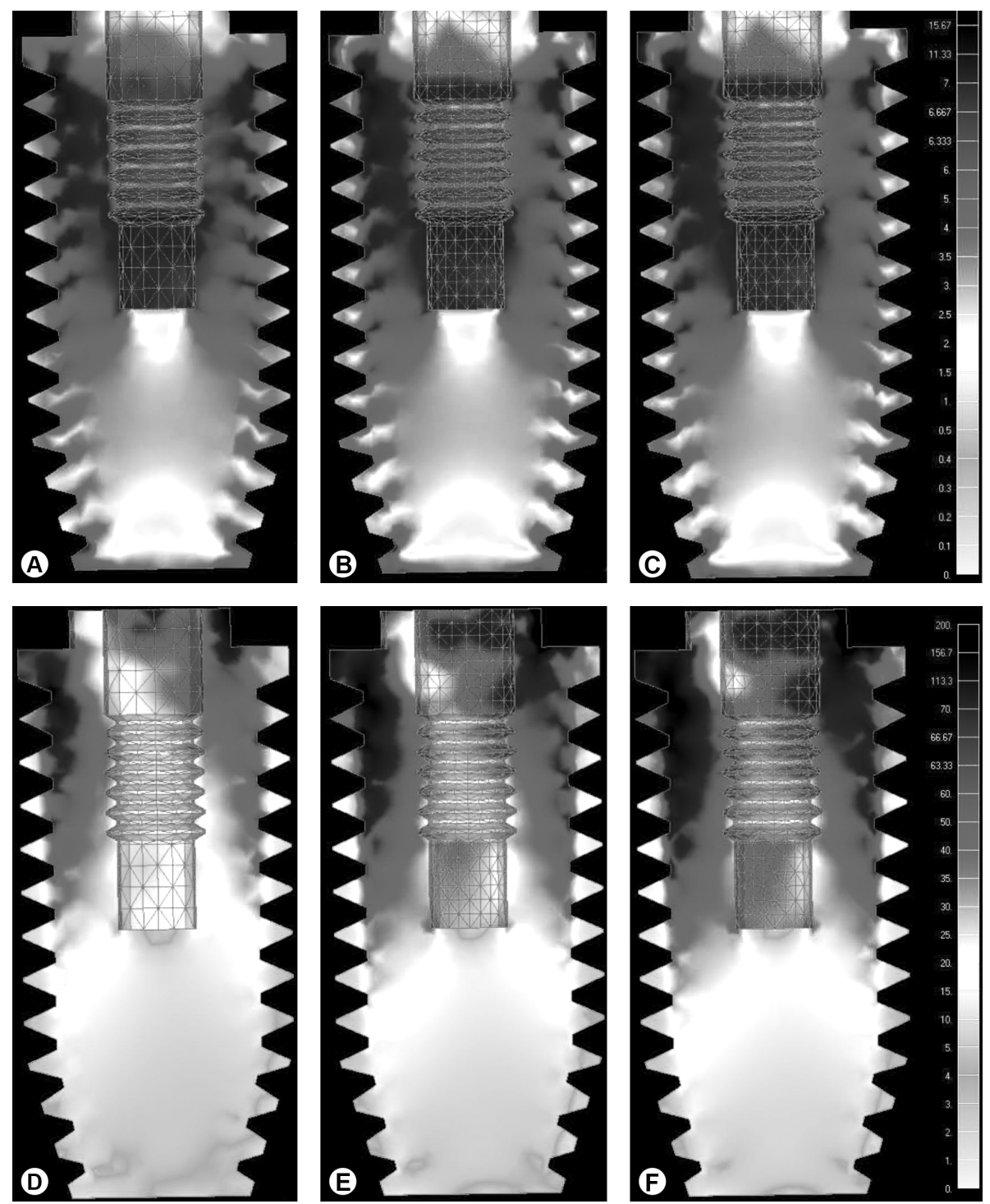

Figure 1. von Mises stress of implant under axial load and functional occlusal force - Height crown:(A) $10 \mathrm{~mm}$, (B) $12.5 \mathrm{~mm},(\mathrm{C}) 15 \mathrm{~mm}$. von Mises stress of implant under oblique load and parafunctional occlusal force - Height crown: (D) $10 \mathrm{~mm}$, (E) $12.5 \mathrm{~mm}$, (F) $15 \mathrm{~mm}$.. 
highest stress concentration. The high intensity stress values ranged from 113.3 to $200 \mathrm{MPa}$.

\section{Screw}

The stress distribution on the retaining screw was similar among the three models, both under functional and parafunctional axial loading. The highest stress was located in a small area at the level of screw thread (Figs. $2 \mathrm{~A}, 2 \mathrm{~B}$ and $2 \mathrm{C}$ ).
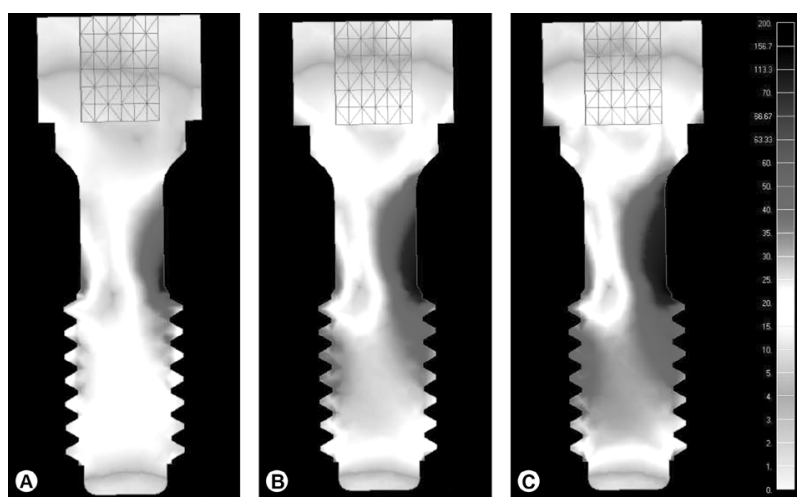

Figure 2. von Mises stress of screw under oblique load and parafunctional occlusal force. Height crown: (A) $10 \mathrm{~mm},(B)$ $12.5 \mathrm{~mm}$, (C) $15 \mathrm{~mm}$.
Under functional oblique loading, the three models also exhibited the same stress distribution pattern and the highest stress was observed in the neck (15-30 MPa) in model C. Under parafunctional loading, the high intensity stresses were located in screw neck, on the same side of load application. The high intensity stress values ranged from 70 to $113.3 \mathrm{MPa}$.

\section{Cortical Bone}

The pattern of stress distribution was similar among the three models, both under functional and parafunctional axial loading (Figs 3A, 3B and $3 \mathrm{C}$ ), but with different magnitudes and concentrations. Models $A$ showed the highest tensile stress ( 0.167 to $1 \mathrm{MPa}$ and 0.833 to 10 $\mathrm{MPa}$, respectively), while models $\mathrm{B}$ and $\mathrm{C}$ presented the most extensive compression stress areas.

Under oblique loading, it must be emphasized that the progressive increase in crown height (Figs 3D, 3E and $3 F)$, induced not only an increase in tensile stress areas (25 to $50 \mathrm{MPa}$ ), but also in areas of compression stress on the contralateral side, although on a larger scale under parafunctional load.

\section{Trabecular Bone}

In a frontal view, tensile stresses were observed on the
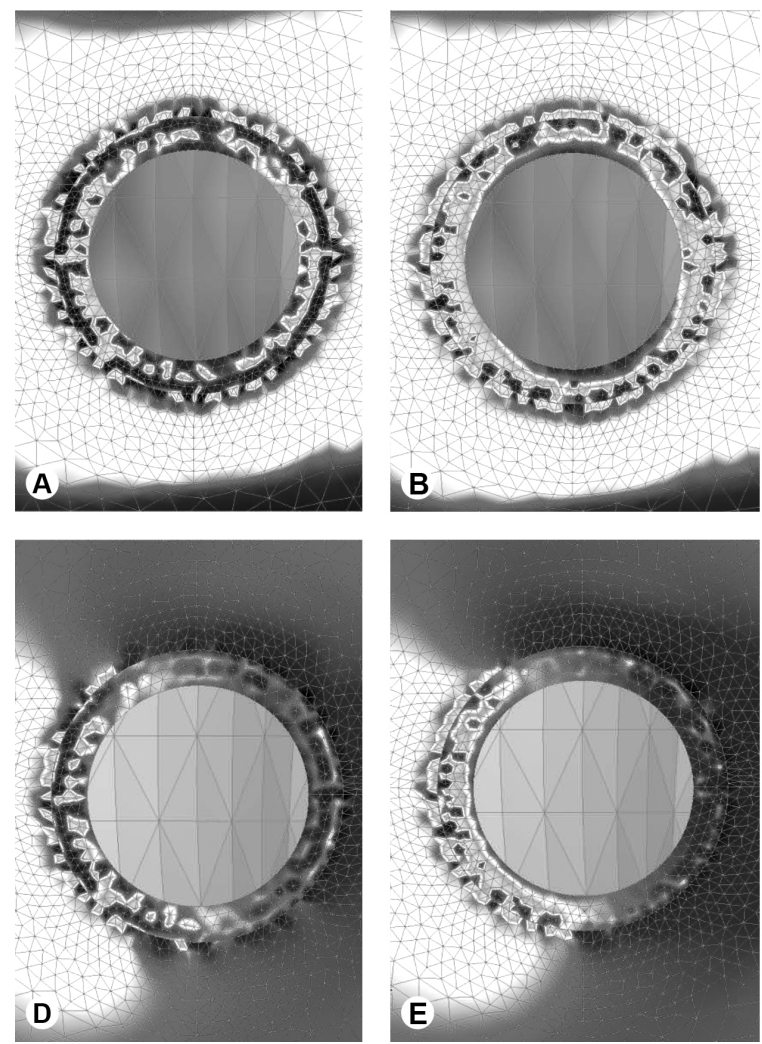
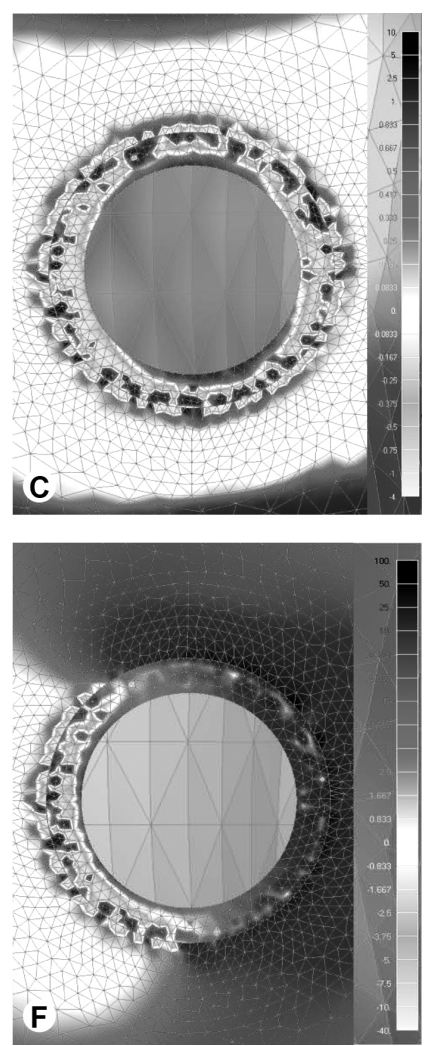

Figure 3. Maximum principal stress of cortical bone under axial load and parafunctional occlusal force - Height crown:(A) $10 \mathrm{~mm}$, (B) $12.5 \mathrm{~mm}$, (C) $15 \mathrm{~mm}$. Maximum principal stress of cortical bone under oblique load and parafunctional occlusal force - Height crown: (D) $10 \mathrm{~mm}$, (E) $12.5 \mathrm{~mm}$, (F) $15 \mathrm{~mm}$. 
tip of threads, and the greatest magnitude was located at the level of first thread under functional (0.417 to $1 \mathrm{MPa}$ ) and parafunctional axial loading (0.833 - $10 \mathrm{MPa})$. Under oblique loading, these stresses were concentrated mainly on the opposite side of load application and showed much greater magnitude in parafunctional (2.5 to $4.167 \mathrm{MPa}$ ) than in functional loading (0.833 to $1.667 \mathrm{MPa}$ ) (Figs. 4A, 4B and 4C).

\section{Discussion}

The effect of $\mathrm{C} / \mathrm{I}(\mathrm{C} / \mathrm{I})$ in peri-implant bone tissue was more evident with the greatest crown height, and stresses were intensified in all models when parafunctional occlusal loading was applied, so the study hypothesis was confirmed. These results were verified by the values of von Mises and maximum principal stresses which showed unfavorable results for the variables "parafunction" and "crown height".

In the study, single crowns were used in order to isolate the studied factor (parafunctional loading and height crown), because if the crowns were splinted, the splinting could reduce stress distribution, modifying the results.

The maximum crown height produced a greater stress concentration, especially under parafunctional occlusal $\therefore$ loading; this may be explained because the crown height acts as a vertical cantilever at the moment of load incidence. This was also observed by Misch et al. (12) who suggested that the crown height represents a potentially more significant factor related to C/I, where the non-axial forces are proportionally intensified (for every $1 \mathrm{~mm}$ increase, stresses rise $20 \%$ ).

Nevertheless, retrospective $(6,17-19)$ and prospective clinical studies $(4,9)$ and a systematic review (7) evaluated the effects of biomechanical factors on single and splinted implant supported prosthesis, and suggested that $\mathrm{C} / \mathrm{l}$ is not a contributing factor to the stability of marginal bone tissue, and is also unrelated to implant or prosthesis failure. The positive results observed by previous authors could be due to the use of internal connection associated with splinting in some cases and with an average C/I of 1.5 (7).

Moreover, other studies based on finite element method corroborate the evidence of the present study by the fact that $\mathrm{C} / \mathrm{I}$ ratio is a biomechanical factor related to stress concentration at the level of prosthetic components and marginal bone crest $(20,21)$. These previous findings may be explained by the high elastic modulus of cortical bone and its smaller surface contact with dental implant, based on engineering principles, in which stresses of larger magnitudes are observed in the region of first contact between two materials (bone/implant) (22). Because cortical bone has a smaller thickness and a higher elasticity modulus than the trabecular bone, it will concentrate higher stresses due to its low deformation and small area of stress distribution.

In a systematic review, Naert et al. (23) related that the potential effects of overload on peri-implant tissue could be ethically analyzed by animal studies, and very few clinical studies obtained from the current scientific literature show high reliability of the obtained data, thus there is no established relationship of cause and effect between parafunctional loads and implant failure. Despite this, Chvartsaid et al. (24) reported the hypothesis of overload and periimplantitis, in which the marginal bone loss and implant failure depend on similar mechanisms, but the occurrence of one or another situation is directly related to the magnitude of trauma.

Despite the divergences among authors, differences in stress distribution pattern regarding the loading type and direction can be explained by the fact that the simulation of a parafunctional activity (bruxism) associated with nonaxial loads could cause occlusal overload in dental implants, their components (11) and the adjacent bone tissue, since the force moments are much higher than those generated

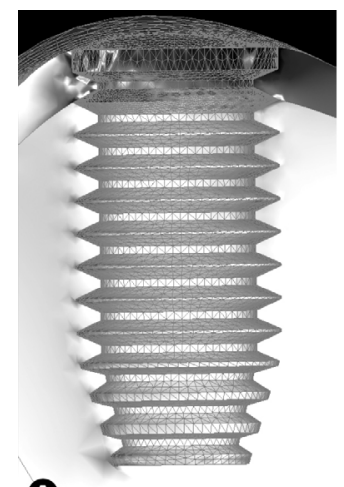

A
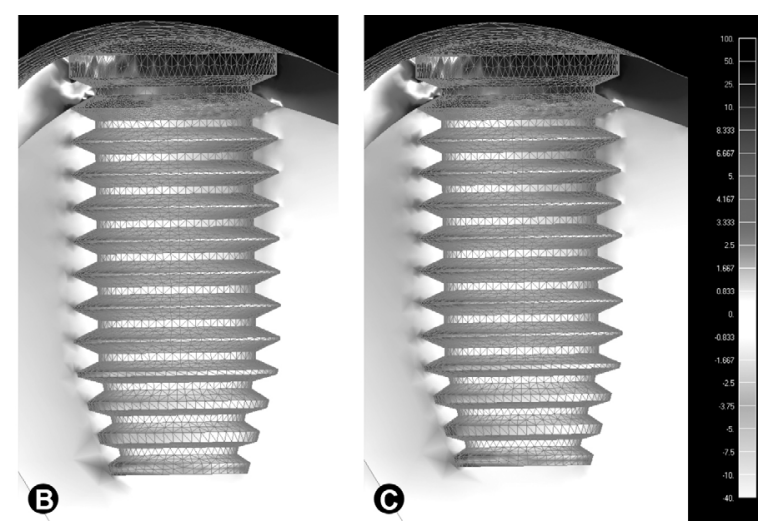

Figure 4. Maximum principal stress of trabecular bone under oblique load and parafunctional occlusal force. Height crown:(A) $10 \mathrm{~mm}$, (B) $12.5 \mathrm{~mm}$, (C) $15 \mathrm{~mm}$. 
in a functional activity. In the present study, parafunctional loading, especially under oblique direction, induced an increase of approximately 33\% of von Mises stress and $60 \%$ of Maximum Principal Stress.

Additionally, the parafunctional loading of the implant with a $1.5 \mathrm{C} / \mathrm{I}$ (crown height with $15 \mathrm{~mm}$ ), which represents the worst biomechanical situation in this study, caused an increase of approximately $6 \mathrm{X}$ in the stress magnitudes in both components and bone tissue. However, according to Misch et al. (25) only a crown height greater than 15 $\mathrm{mm}$ is considered biomechanically unfavorable, since the generated peri-implant stresses could cause screw loosening or fracture, marginal bone loss, prosthesis fracture, failure and even implant fracture.

Concerning the complications of external connection, the crown retaining screw is the weakest point of the implant/prosthesis joint (2), also confirmed by the results obtained from this study, in which higher stress concentration was observed at the screw neck as an opposed effect to the displacement of the crown, especially when simulating parafunctional oblique activity.

The stresses were more intense under parafunctional oblique loading, in which the direction and magnitude of the force may influence the applied load on the implant and the stress transfer to the supporting bone. Clinically, an appropriate occlusal adjustment, the reduction of occlusal table and decreasing the slope of the cusps allow better distribution of occlusal forces and minimize the stress in the supporting structures. In addition, it is recommended that, at nighttime, the patient uses a hard acrylic interocclusal appliance with appropriate disocclusion guides.

Based on the used methodology, it was concluded that: 1. Increasing the crown/implant proportion enhanced the stress concentration on both implant components and cortical bone; 2. Parafunctional loading increased between 4-5 times the stress magnitude in bone tissue compared to the functional loading; 3 . The type of loading is a variation factor more influential than the $\mathrm{C} / \mathrm{I}$

\section{Resumo}

0 objetivo deste estudo foi avaliar, através do método dos elementos finitos tridimensionais, a influência do carregamento oclusal parafuncional e da altura da coroa na distribuição das tensões em próteses unitárias implantossuportadas de hexágono externo. Foram confeccionados três modelos com o auxilio de programas de desenho assistido. Cada modelo foi composto por um bloco ósseo da região molar mandibular, por um implante de tipo hexágono externo $(5 \times 10,0 \mathrm{~mm})$ e por coroa com diferentes alturas: 10, 12,5 e $15 \mathrm{~mm}$. Os modelos foram exportados para o programa de elementos finitos NEiNastran 9.0, para geração das malhas e estabelecer as condições de contorno. Aplicou-se uma carga funcional (200 N axial e $100 \mathrm{~N}$ obliqua), bem como uma carga parafuncional $(1.000 \mathrm{~N}$ axial e $500 \mathrm{~N}$ oblíqua). Os resultados foram visualizados por meio de mapas de Tensão de von Mises e mapas de Tensão Máxima Principal. 0 carregamento parafuncional induziu um aumento da área de distribuição e da magnitude das tensões no implante (plataforma e primeiras roscas) e parafuso (pescoço) em comparação com o carregamento funcional. A cortical óssea apresentou maiores áreas de tensão por tração sob carregamento parafuncional obliquo. A concentração de tensões aumentou à medida que aumentou a altura da coroa. 0 aumento da altura da coroa induziu um aumento na concentração de tensões, tanto nos componentes do implante, quanto na cortical óssea; o carregamento parafuncional induziu um aumento entre 4-5 vezes da magnitude das tensões no tecido ósseo; o tipo de carregamento apresenta-se como um fator de variação mais influente do que a proporção coroa/implante.

\section{Acknowledgements}

This work was supported by The São Paulo State Research Foundation (FAPESP - grant \#2011/03624-0).

\section{References}

1. Kreissi ME, Gerds T, Muche R, Heydecke G, Strub JR. Technical complications of implant-supported fixed partial dentures in partially edentulous cases after an average observation period of 5 years. Clin Oral Implants Res 2007;18:720-726.

2. Kim Y, Oh TJ, Misch CE, Wang HL. Occlusal considerations in implant therapy: Clinical guidelines with biomechanical rationale. Clin Oral Implants Res 2005;16:26-35.

3. Laney WR. Glossary of oral and maxillofacial implants. International team for implantology. Berlin: Quintessence Publishing, 2007.

4. Blanes RJ, Bernard JP, Blanes ZM, Belser UC. A 10-year prospective study of ITI dental implants placed in the posterior region. II: Influence of the crown-to-implant ratio and different prosthetic treatment modalities on crestal bone loss. Clin Oral Implants Res 2007,17:707-714.

5. Gómez-Polo M, Bartens F, Sala L, Tamini F, Celemín A, del Rio J. The correlation between crown-implant ratios and marginal bone resorption: A preliminary clinical study. Int J Prosthodont 2010;23:3337.

6. Birdi H, Schulte J, Kovacs A, Weed M, Chuang S-K. Crown-to-implant ratios of short-length implants. J Oral Implantol 2010;6:425-433.

7. Blanes RJ. To what extent does the crown-implant ratio affect the survival and complications of implant-supported reconstructions? A systematic review. Clin Oral Implants Res 2009;20:67-72.

8. Stanford CM, Brand RA. Toward an understanding of implant occlusion and strain adaptive bone modelling and remodelling. J Prosthet Dent 1999;81:553-561.

9. Tawil G, Aboujaoude N, Younan R. Influence of prosthetic parameters on the survival and complication rates of short implants. Int J Oral Maxillofac Implants 2006;21:275-282.

10. Van den Bogaerde L, Pedretti G, Dellacasa P, Mozzati M, Rangert B. Early function of splinted implants in maxillas and posterior mandibles using Branemark system machined-surface implants: an 18-month prospective clinical multicenter study. Clin Implant Dent Relat Res 2003;5:21-27.

11. Lobbezoo F, Brouwers JEIG, Cune MS, Naeije M. Dental implants in patients with bruxing habits. J Oral Rehabil 2006;33:152-159.

12. Misch CE, Suzuki JB, Misch-Dietsh FM, Bidez MW. A positive correlation between occlusal trauma and peri-implant bone loss: literature support. Implant Dent 2005;14:108-116.

13. Sevimay M, Usumez A, Eskitascioglu G. The influence of various occlusal materials on stresses transferred to implant-supported prostheses and supporting bone: A three-dimensional finite-element study. J Biomed Mater Res B Appl Biomater 2005;73:140-147.

14. Sertgöz A. Finite element analysis study of the effect of superstructure material on stress distribution in an implant-supported fixed prosthesis. Int J Prosthodont 1997;10:19-27.

15. Anusavice KJ, Hojjatie B. Stress distribution in metal-ceramic crowns with a facial porcelain margin. J Dent Res 1987;66:1493-1498.

16. Eraslan O, Sevimay M, Usumez A, Eskitascioglu G. Effects of cantilever design and material on stress distribution in fixed partial dentures - a finite element analysis. J Oral Rehabil 2005;32:273-278.

17. Schulte J, Flores AM, Weed M. Crown-to-implant ratios of single tooth 
implant-supported restorations. J Prosthet Dent 2007:98:1-5.

18. Urdaneta RA, Rodriguez S, McNeil DC, Weed M, Chuang SK. The effect of increased crown-to-implant ratio on single-tooth locking taper implants. Int J Oral Maxillofac Implants 2010;25:729-743.

19. Anitua E, Piñas L, Orive G. Retrospective study of short and extra-short implants placed in posterior regions: Influence of crown-to-implant ratio on marginal bone loss. Clin Implant Dent Relat Res 2013 [Epub ahead of print. DOI: 10.1111/cid.12073.].

20. Sütpideler $M$, Eckert $S E$, Zobitz $M, A n K N$. Finite element analysis of effect of prosthesis height, angle of force application, and implant offset on supporting bone. Int J Oral Maxillofac Implants 2004;19:819825.

21. Sotto-Maior BS, Senna PM, da Silva WJ, Rocha EP, Del Bel Cury AA. Influence of crown-to-implant ratio, retention system, restorative material, and occlusal loading on stress concentrations in single short implants. Int J Oral Maxillofac Implants 2012;27:e13-e18.

22. Kitamura E, Stegaroiu R, Nomura S, Miyakawa O. Biomechanical aspects of marginal bone resorption around osseointegrated implants: considerations based on a three-dimensional finite element analysis. Clin Oral Implants Res 2004;15:401-412.

23. Naert I, Duyck J, Vandamme K. Occlusal overload and bone/implant loss. Clin. Oral Implants Res 2012;23:95-107.

24. Chvartsaid D, Koka S, Zarb G. Osseointegration failure. In: Zarb G, Albrektsson T, Baker G. et al., (eds). Osseointegration: on continuing synergies in surgery, prosthodontics, biomaterials. Chicago: Quintessence; 2008. p. 157-164.

25. Misch CE, Steignga J, Barboza E, Misch-Dietsh F, Cianciola U, Kazor C. Short dental implants in posterior partial edentulism: A multicenter retrospective 6-year case series study. J Periodontol 2006;77:13401347.

Received July 7, 2014

Accepted November 7, 2014 